\title{
A Theoretical Study On Factors Influencing Employees Performance, Rewards And Motivation Within Organisation
}

\author{
https://doi.org/10.21272/sec.4(3).113-124.2020.
}

Md Zahid Al Mamun, ORCID: https://orcid.org/0000-0002-7761-1796

MBA, Independent Human Resource Management Advisor, Member of The Association of Business Executive-ABE, Bangladesh

\section{Md Yusuf Hossein Khan, ORCID: https://orcid.org/0000-0002-5981-8849}

Ph.D. Researcher in Tourism, University of Algarve, Faro, Portugal; Assistant Professor, College of Tourism and Hospitality Management, IUBAT - International University of Business Agriculture and Technology Dhaka, Bangladesh

\begin{abstract}
Under modern conditions, human resources and their motivation to work are an essential component of the success of enterprises operating in a changing and global competitive environment. It is because of the interest of the company's employees in the results of their work, provided that appropriate working conditions are created, it is possible to increase labor productivity, as well as improve the economic and financial performance of the company. The purpose of the article is to identify the factors that affect the efficiency of the company's employees and encourage them to work. The results of systematization of scientific research have shown that high staff productivity is not possible without a system of rewards and motivation. The study of improving the efficiency of employees in the article is carried out in the following logical sequence: analyzed modern views on personnel management, studied the relationship between the structural elements of personnel management policy: efficiency, remuneration and motivation, developed a mechanism for managing staff efficiency. The methodological basis of this study is qualitative methods, which allowed to gain a deeper knowledge of the behavior of employees. Recommendations for building a system of personnel efficiency management are offered, which will allow to retain employees, increase labor potential, as well as improve the efficiency of the whole business. Emphasis is placed on the need to introduce not only material rewards, but also to take into account other components in building the company's personnel policy: a favorable corporate environment, quality communication between employees and management, implementation of coaching, rational division of responsibilities between employees, participation in management decisions. The obtained results have practical significance and can be useful for the top management of the company in the context of strategic personnel management.
\end{abstract}

Keywords: employee performance, human resource management, motivation, organization, rewards.

JEL Classification: J33, O15, P47.

This work is licensed under a Creative Commons Attribution 4.0 International License.

Cite as: Mamun, M. Z. A., Khan, M. Y. H. (2020). A Theoretical Study On Factors Influencing Employees Performance, Rewards And Motivation Within Organisation. SocioEconomic Challenges, 4(3), 114-124. https://doi.org/10.21272/sec.4(3).114-124.2020.

(C) The Authors, 2020. This article is published with open access at Sumy State University.

\section{Introduction}

HRM always deals with the first $\mathrm{M}$ among the five Ms of management, i.e., men, money, machines, materials, and methods which indicates that the "men" is the most critical one among all these five Ms and not so easy to manage (Credit Acceptance, 2004). It is an obvious that every men is different from other and in the context of management five Ms they are entirely different from other Ms in the sense that men possess the power of manipulate other Ms whereas the other Ms can't as they are whether lifeless or just abstract, as such do not possess the power to think or decide what is good for. Them. Human being is fundamental resource for producing or developing of anything, as because behind production of every product or service there is a 
human mind, effort and man hours (working hours). Without the help of human being or human mind, no product or services can be produced. Usually human resource management is there for making sure proper and efficient use of available skilled workforce and also to make appropriate plan to use existing human resource within an organization.

Humans or human capital are of the utmost important assets for any organization, although now a days many tasks have been handing over to the artificial intelligence, but they lack judgement skills which cannot be matched with human mind.

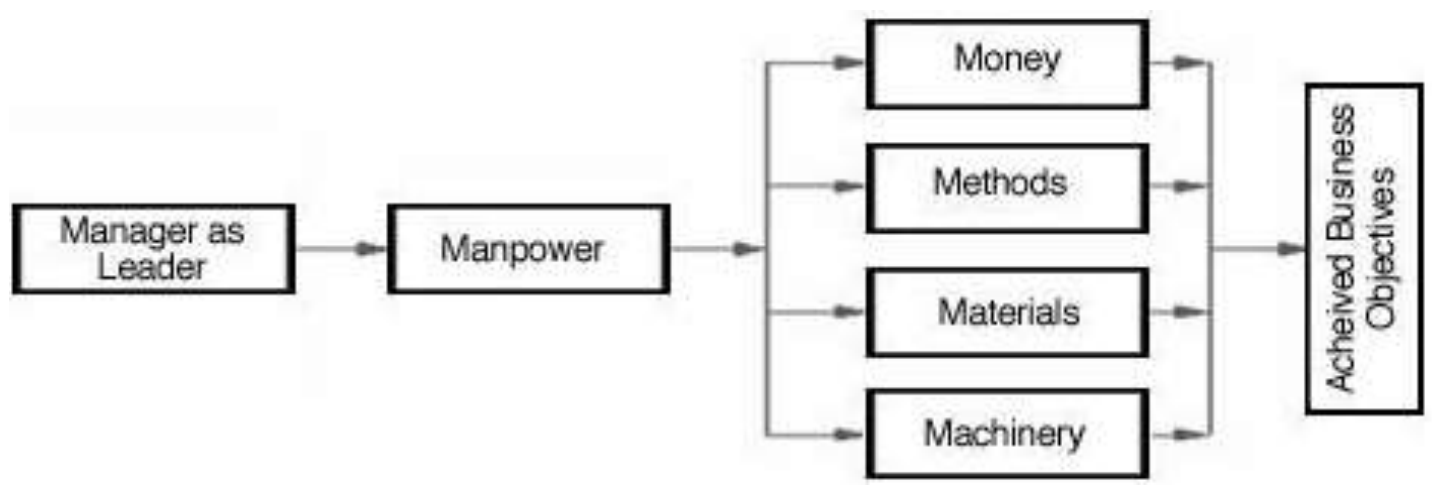

Figure 1. The Five Ms of Management

Source: ASTD (2004), Alexandria, VA.

Human Resource Management (HRM) is a term that usually use for describing formal systems devised for the management of people with an organization. HRM is the process of recruiting, selecting, inducting employees, providing orientation, imparting training and development, appraising the performance of employees, deciding compensation and providing benefits, motivating employees, maintaining proper relations with employees and trade unions, ensuring employees safety, welfare and health measures in compliance with labour laws of the land. Michael Armstrong in his book "A Handbook of Human Resource Management" motioned that, business success is most likely to be achieved in the personnel policies and procedures of the enterprise are closely linked with and make major contribution to the achievement of corporate objectives and strategic plans. According to Best Practices, LLC businesses must constantly adapt their strategies and goals to address the dynamic forces of the shifting challenges and opportunities of global markets, the organizational upheaval of mergers and acquisitions, and the rapid evolution of productivity tools and technologies. One critical - but frequently overlooked - dimension of this process of renewal is the impact of organizational change on employee motivation and behavior. Personnel involved in decision making for rewards and recognitions needs to observe carefully that the existing process they have are aligned with overall strategic and operational goals. Misaligned system on rewards and recognitions may result in such behaviours from the employees that is not anticipated or desired by management. These unanticipated actions may be personally beneficial to front-line sales reps, manufacturing floor managers or even senior executives, yet they move the company away from its overall goals or cause systemic harm. Once an organization believes to determine its upcoming mission and willing to achieve them, it is then relying on the employees, as they will be the key to do the necessary work geared towards achievement of the organizational goal and success through their performance (Khan, 2018). In addition to help measure employee reception, a well-defined performance measurement system help in the process towards corporate goals. This present study aims to review how a proper performance related reward system can be used as a tool to enhance work performance. The study includes different performance related reward systems that may be embraced by management to foster work performance, what performance appraisal measures need to be put in place to motivate employees and the relationship between performance related reward systems and work performance.

\section{Literature Review}

Performance management is an established management process which is observed as the "framework of policies and practices" established for "planning, monitoring, developing, evaluating and rewarding both individual and organizational performance and for using performance information in making personnel decisions". remarkably, this is much broader in focus than a job description (Thompson, 2007). Performance rewards came in picture in recent years for so many reasons. This make sure that rewards are given to 
employees to excel their motivation, limit employee-employee conflicts and making sure fair rewards treatments. According to Sara Indileni Hamukwaya and Rashad Yazdanifard (2014), dissatisfaction at work, poor work performance, negative attitudes, lack of motivation and agency problems can also be included a response to a call of worker's. These "ills" will only be "cured" if there are proper performance measures in place and every organisation should practice this to enhance its organisational performance. One of the best ways to put forth this is to put in place a proper performance-based reward system and this is usually based on three factors: ability, motivation and resources (Luccier, 2009). This implies that for greater work enhancement, all the aforesaid factors must be high. In other words, organisational rewards must be linked to work performance to achieve better or improved organizational results provided that the organisation have enough resources and employees are trained to carry out their jobs. According to Mclagan and Nel as cited in Tsai, Chou \& Chen (2008) rewards are signification lever to shape employees toward any craving goal of the organisation. Thirst for goals stated here can be greater profits on investment, improved customer services, securing greater market shares, competitive advantage and all that accord to the success of any organisation. With tremendous technological advancement at the workplace, the focus of attention has been on knowledgebased workers to meet the dynamic needs of the society (Holbeche, 2009; Kuruvilla and Ranganathan, 2010). To accomplish competitive advantage, organizations are more apprehensive with the skills and the quality of their employees to ensure sustained performance (Reiche, 2007) and retaining skilled and quality employees are becoming the top strategic policy issue for many organizations (Heinan and O'Neill, 2004; Bersin, 2008; Holbeche, 2009). Literature is full of empirical researches indicating that organizations adopt various policies and strategies to retain employees (Sheridan, 1992; Pamela, 2003; Samuel and Chipunza, 2009; Price, 2003; Holland, et al., 2007; Hom, et al., 2008). One strategy that has been implemented recently is that of total rewards, which targets to maximize the combined effect of reward elements on motivation and commitment, and embraces all that employees value in their employment ship (Sweeney and Mcfarlin, 2005; Anku-Tsede and Kutin, 2013; Cao, et al., 2013; Kaplan, 2007; Armstrong, 2009). Total rewards including the traditional pay and benefits, employees receive as part of their employment, as well as other programs that help make the work experience more satisfying that is work-life balance, career mobility, acknowledgement etc. (Cao, et al. 2013; Durrani \& Singh, 2011; Medcof \& Rumpel, 2007). Milne as cited in Tsun, Shang and I-Jan (2007) and Gross, Elhayney, Friedman and Buetow (2008) specified that organizational rewards are some of the mechanisms that can be used to encourage knowledge sharing, quality of work, motivation for efforts (Barth, Bratsberg, Haegeland, Raaum (2008) as well as performance among organizational members. This denotes that if workers and work teams are rewarded according to their performance, they will make significant contributions to their organizations. Therefore, it is ultimate importance for every organization to decide how best way to reward their employees and on what basis will they be rewarded. All of the organization's assess rewards as a means of motivating certain performance in employees. Specifically, rewards are proposed to motivate employees to perform effectively and efficiently towards achieving organizational goals. Malhotra et al. (2007:20-95) despite any organization's outlooks rewards play an important role in manufacturing and preserving the commitment among employees that guarantees a high standard of performance and workforce stability. None the less, Shanks (2007:24) however argues that although rewards may serve as incentives and those who grant rewards may seek to use them as motivators; the real motivation to perform, comes from within the individual. Conventionally, according to Beer et al (1984), reward and recognition programmes were undefined and there was a lack of set standards to measure outstanding performance. Since the 1980's, there have been significant changes where in current organisational settings, reward and recognition is directly linked to the business strategy because organisations have a great understanding of the massive gains being achieved (Flynn, 1998). Organizational rewards encourage working effectiveness by providing a means of recognition of accomplishment, particularly by motivating and improving employee engagement; money as a financial reward are not automatically effective as motivation.

\section{Performance, Rewards and Motivation}

As we know that performance derived from the word "perform" according to the oxford dictionary; which means to carry out, accomplish or fulfil an action, task or a function. The performance reward for completing a task(work) or a function is what is termed as motivation. All though people work for salary (money) or wages (rewards), there are several ways of rewarding (motivating) employees according to the work, task or function performed. Employee performance can be portrayed as a process by which organizations set goals, determining standards, assign and appraise work, and distribute rewards (Varma et al, 2008). It is accustomed to improving organizational, team and individual performance and development, including activities designed 
to ensure that goals are consistently being met in an effective and efficient manner. Performance is an ongoing activity relating to all scenarios where people meet for the purpose of attaining organizational objectives. The empirical research and the available data indicate that 90 percent of U.K organizations formally assess managers via a performance management system, compared with 88 percent in Greece and Sweden, 84 percent in Ireland and 81 percent in Germany (Brewster et al., 2007; McMahon, 2009). Employee performance management also highlights the ongoing nature of the staff management process of the organization. By relating to this, Torrington et al. (2008) call attention to that 'performance management' is increasingly seen as the way to administer employee performance and has incorporated the appraisal/review process. In that matter, Armstrong (2009:9) recommends that performance management is a 'systematic process' for improving organisational performance, through the development of the performance of individuals and teams. Therefore, we can say that within an agreed framework of planned goals and objectives, maintaining the standards and unavoidable competency requirement, it is a means of receiving enhanced results, as one manages performance in a manner which focuses on future performance planning and development. This progression entails the provision of feedback and the assessment of an employee's evolvement and achievements, so that action plans can be organised.

\section{Performance Management Systems Design:}

- To evaluate employee performance with view to knowledge sharing experience.

- To undertake major objectives and investigate ideas for the enhancement of results succeeded.

- To accommodate job holders in analysing their own potencies and improvement needs.

- To oblige the employee in the association of training needs and other remedial creativities and in the assessment and encroachment of their potential and career growth prospects through the provision of appropriate backings including education, coaching, mentoring, counselling, performance enhancement plans and so on.

- To protect feedback on how effectively the employee has been accomplished or supervised.

- To guarantee that the job holder is fully conscious of how management view his/her performance and contribution in the organization.

- To serve with planning that what would be the pay increases or what would be salary levels.

- To preserve equity in the evaluation and treatment of employees, via usage of a standard performance review and a related demands system.

- To discourse the problem of sub-standard employee performance, and to serve with decisions in regard to employee retention. Ultimately this decision may help the organization's defence against illegal allegations of unfair dismissal or discrimination in all HRM activities.

- To sustain reorganized set of personnel records for such determinations as the familiarisation or ambitions of inherited staff the validation of selection procedures and employee retention decisions.

Source: Adapted from McMahon and Gunnigle (1994:11).

\section{Performance Management Process}

Performance management is a combined goal setting, performance appraisal and development into a single common system, the purpose of which is to safeguard that the employee's performance is accompanying the company's strategic goals (Peter Glendinning, 2002).

\section{Reward}

Reward is the generic term for the totality of financial and non-financial reimbursement or total remuneration paid to an employee in return for task or service rendered at workplace. Reward, which is sometimes been indicate to as compensation or remuneration, is perhaps the most principal contract term in every compensated employee. According to Armstrong (2010) reward management is expressed "as the strategies, policies and process required to confirm that the usefulness of people and the contribution they create to attaining organization, departmental and team goals is acknowledged and rewarded. The prime target of reward system is to emphasize the drive to improve organizational effectiveness and productivity. The efficiency differs on the capability to draw, preserve and motivate with financial and non-financial reward incentives for the people of the quality required by the organization (Shields, 2007). Malhotra et al (2007) explain rewards as 'all forms of financial and non-financial return, tangible services and benefits an employee receives as part of an employment contacts. There is no uncertainty that each employee expects some level of reward after 
delivering a work, function or task. Employees presume employers to deliver or execute selected duties to their satisfaction at the same time as employees also expect their employers to assure them of acceptable financial and non-financial rewards after they respectfully deliver what is expected of them.

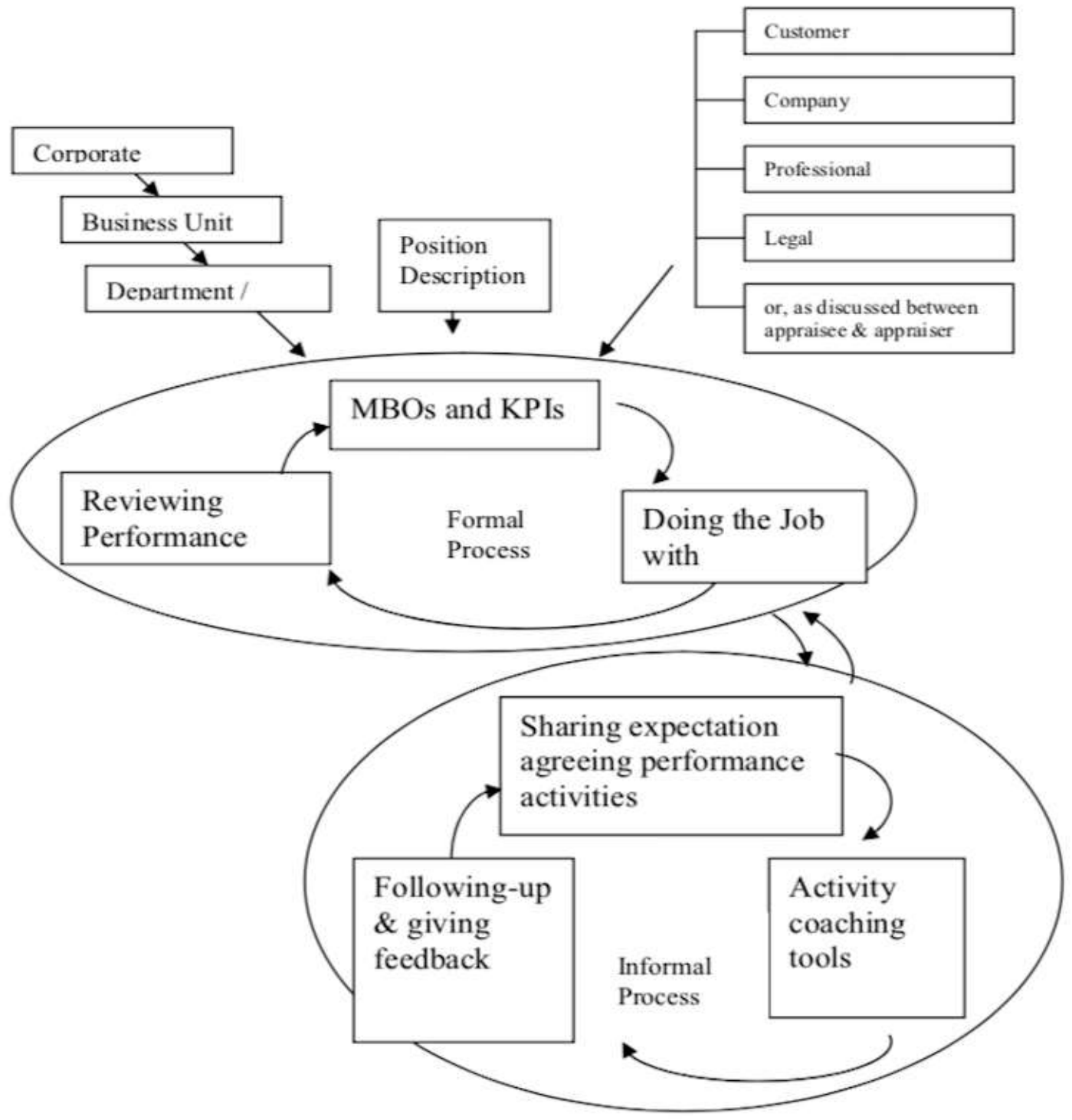

Figure 2. Performance Management Process

Source: Practices of Performance Management System in Bangladesh: An Empirical Study among Three Different Industries.

Human beings are by nature not homogeneous entity. They have a diversity of prerequisites, aspirations, as well as differing perceptions of what constitute appropriate rewards for effectual motivation. That is why organization requires an in-depth understanding of motivating workers who are dissimilar by the human nature, individual differences and perceptions of appropriate rewards and incentives, as well as a combination of extrinsic and intrinsic rewards. Approximately most of the organizations considered rewards as a means of motivating undeniable behaviours in employees. Specifically, rewards are envisioned to motivate employees to perform commendably and efficiently towards succeeding organizational goals. Malhotra et al. (2007) comment that rewards play an important role in building and maintaining the commitment among employees that ensures a high standard of performance and workforce stability by overlooking the organization's size or types. The rationale for the use of rewards is to motivate or induce certain behaviours among employees which are viewed as favourable for increased performance whereas inhibiting other behaviours which they perceive as detrimental to organizational growth and performance. There is no doubt that this is the best achieved under what Vroom terms as expectancy models. On the other hand, Martin (2005) argues that the basis of expectancy 
models is that motivation is a function of the desirability of the outcome of behaviour. That is to say, an individual employee is motivated to produce projected behaviour if he or she is convinced that behaviour will lead to assured rewards. The authors experience in a knowledge economy where the greatest strength an employee can conciliation an organization, is their intelligence, experience, problem solving ability and change- perception persona. This is widely practised that intrinsic rewards are especially meaningful to workers. In fact, the leading theorists of workplace motivation (Frederick Herzberg) found that intrinsic rewards to be considerably stronger than extrinsic or financial rewards in growing employee motivation. This is obvious that employees will seek financial rewards in addition to intrinsic rewards, rather it just means that money is not good enough to maximize motivation to most employees. Actually, employees desire to feel like their contributions in their respective workplace really matter.

\section{Motivation}

Recently, businesspeople are facing tremendous challenges of ever-changing human nature in workplace in terms of employee performance. It is employees who have the most bargaining power not only for massive salary as reward but also for motivational incentives. So, Motivation is a fascinating, challenging, and complicated zone of Human Resource Management studies which is swiftly changing both in terms of its nature, understanding, functions, purpose, as well as mode of application. Now a day's manager has to present and work with employees at the designated workplace otherwise it will not perform efficiently as required. Employers do not expect their employees to just show up at workplace but most supremely they required to be motivated to execute their responsibilities for work. That is why, motivation should be explain as an energetic force which will leads employee to ought to act, carry out, or produce something without pressure or undue manoeuvring. Abraham Maslow's (1954) presented the theory of 'Hierarchy of Needs' in his book Motivation and Personality. The Hierarchy-of-Needs theory concentrated on the idea that human beings are motivated by unsatisfied needs, and that the attainment of a lower need only leads to the quest for the satisfaction of a higher need. Physiological, survival, safety, love, and esteem are the Maslow's classification of human needs as he categorised those five elements as pyramid structure. He did not forget to mention that for an individual to act unselfishly, there are no way, but all five needs must be satisfied. He termed these needs 'deficiency needs. In our lifelong as we are motivated to satisfy these cravings, we are moving towards growth, eventually at the peak toward self-actualization.

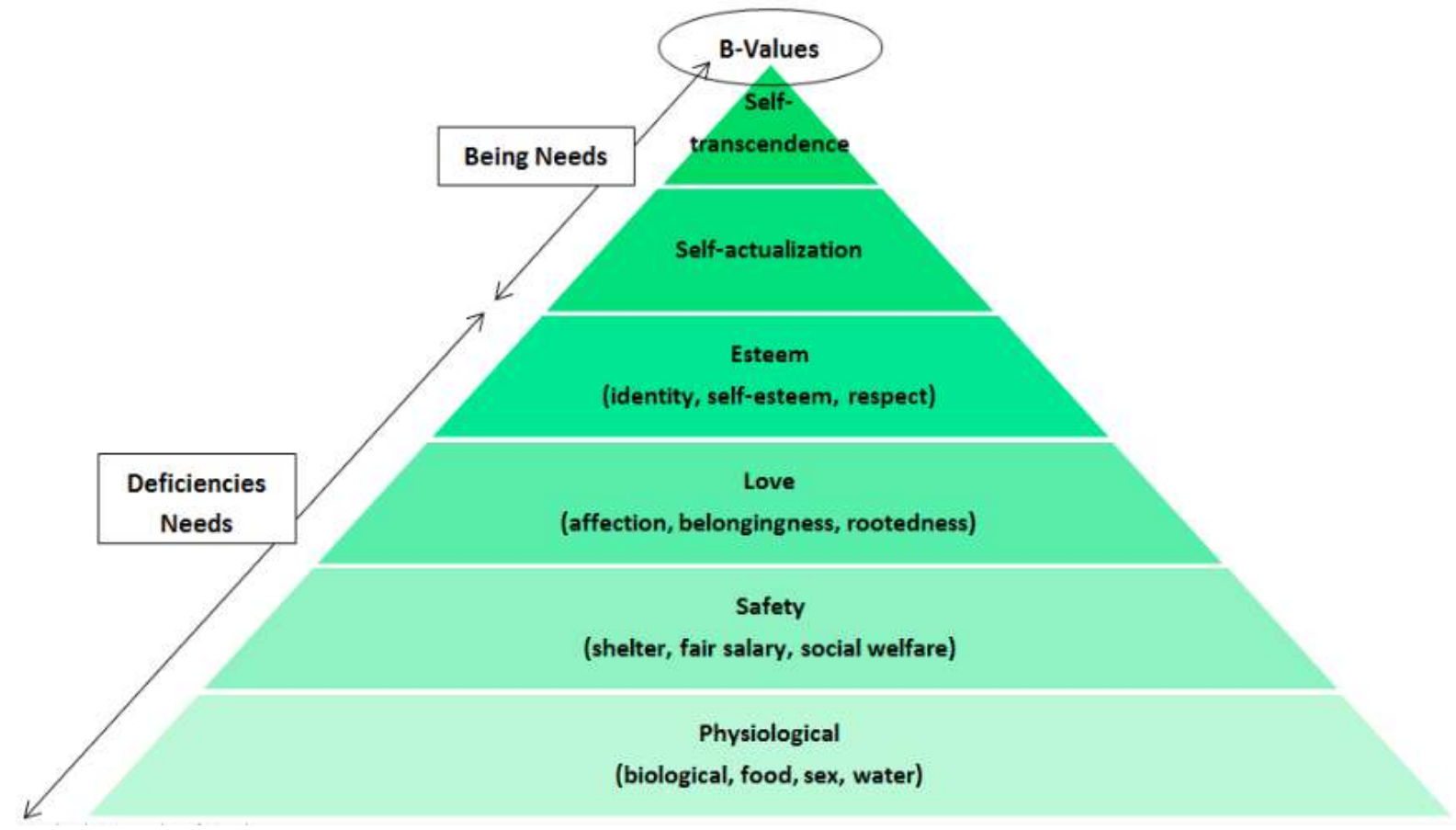

Figure 3. Maslow's Hierarchy-of-Need Model

Source: Businesshumanizer (2017), Book review: A Theory of Human Motivation. 
Another management theorist Victor H. Vroom (1964) observed at the whole paradigm of motivation in a somewhat different perspective. He presented the expectancy theory of motivation as a function of mental process regarding choice or desirability of the outcome of behaviour. Expectancy theory also referred to as the path-goal-theory; which suggests that rewards are attributed to certain behaviours. If an individual supposes that behaving in a particular way will generate rewards that the individual values or seek, they will be motivated to behave in line with what is expected of them., Vroom summaries the importance of such factors as effort to motivation and performance in work-motivation which is differ from Maslow and Herzberg. He emphasizes the needs for organizations to relate rewards directly to performance in this theory that the rewards granted are those rewards for a person to be motivated and well deserved and long for by the recipients. So, effort, performance and motivation (outcome), must be linked (See Figure 4). Vroom propositions three factors that account to motivation as:

a. Expectancy

b. Instrumentality

c. Valence

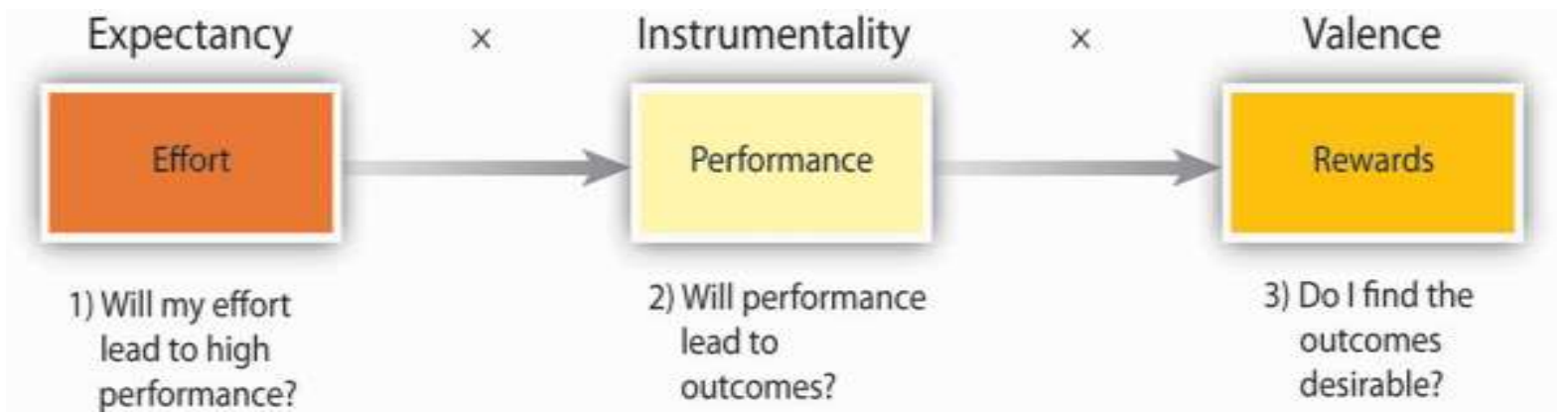

Figure 4. Vroom's Expectancy Model

Source: PSYCH 484, Work Attitudes and Job Motivation.

\section{Findings and Discussion}

\section{The Links between Performance, Rewards and Motivation}

As it was mentioned before the process of motivation involves a partnership attitude between management of an organization and its employees. Superiors/managers can however play a major role by developing great indepth understanding of the linkages between motivation, performance and rewards to help their workers to stay motivated and focused on the job assigned. None the less, this is because the process of motivation demands more than just the endowment of adequate rewards. However, it incorporates other equally vital components some of which are discussed below.

Building an Enabling Environment: To achieve the best performance in any organization there are no other way around except motivated employees to work along managers. There is often-overlooked factor is the environments under which work activities take place. If the work environment is not conducive, unfavourable or there exists negative attitude, it will become problematic for employees to be motivated. Bessell et al, debate that 'if a manager, supervisor or team leader approaches the workplace with a positive vibe, upbeat attitude about the work projects, that positive energy should transfer to associates, fellow workers, thus will create comfort, joy eventually a better work environment' (2002:2) and vice versa. On the other hand, it is crucial that superiors are instructed to ensure that behaviours are either rewarded or punished in a timely manner. As Dubrin (2004:302) opine that 'for maximum effectiveness, employee should be rewarded as quickly as possible after doing something accurately and punished shortly after doing something negatively in terms of duties. Not only that other issues which can impact the work environment in one way or the other pertains to mutual respect between managers and employees.

Communication: Without communication it is impossible to keeping employees motivated and helps in maintaining a 'motivated culture' in the workforce. Therefore, managers or superiors should introduce 'a system of regular staff appraisals and they should emphases that it is essential to clearly articulate what the objectives of the business are (Adkins 2006:26). After establishing that environment, employees will get a 
crystal-clear sense of what is expected of them to perform. Managers should stress further that employee should know how they will contribute to the company and how they will make a difference.

Role Clarification: Malhotra et al. (2007:2102) define role clarity is the degree to which employees distinguish that required information is provided about how the employee is expected to perform their duties. They declare the significance of role clarification to employee commitment, motivation, and performance. Further, they express that such employees are more likely to be committed and motivated to work than those who perceive ambiguity in their job functions or that their roles have not been adequately clarified.

Coaching: Coaching unlock the individual's potential to maximise his/her own performance. Coaching has been distinguished to be an art of management which when done properly, it fosters the level of motivation in employees. Company authorities on management styles have noted that coaching proceeds a paradigm shift from traditional management style which focuses on control, compliance and even punishment. It is universally accepted that managers efforts on coaching to unravel actions and behaviours which allows employees to be more productive in the work environment. Management theorist Dubrin said that 'because of the uniqueness of a coaching relationship, the person being coached is better motivated to accomplish goals for the good of the organization (2004:309).

Participation in Decision Making: Not so long ago, employees were considered as only task doer similar to robot or task-tools. However, situation has changed so rapidly that this is the degree to which employees perceive that their input with regard to decision making is valued or that they are able to influence decisions at the workplace especially with regards to their job-related functions. In addition, Malhotra et al (2007:2102). argue that employee participation or engagement in decision making is seen as an indirect means of communicating managerial expectations of work behaviour and can be a motivating force for employee performance at work setting.

Feedback: Feedback is the output of a system where input back into the system as part of a chain of cause and effect. Many researchers have advertised the importance of feedback that managers give to employees have great influence on motivation (Young et al. 1998, Malhotra et al. 2007, Hackman \& Oldham 1976). According to researcher Malhotra et al, (2007:2102) feedback includes the recognition and compliment acknowledged from immediate superior for good service delivered. Armstrong (2001) emphasizes that feedback is an important intrinsic motivational tool among other rewards. In this modern time, it is very important to note for superior authorities that the effect of feedback on employee motivation is heightened when it is specific rather than generalized and given in a timely manner. This will allow the employees to focus and dedicated on their own performance where require improvement and which one to carry on.

\section{Drawbacks of Rewards on Performance}

According to the several authors, money cannot buy everything and this is even more useful in business organization. The application and uses of monetary rewards and benefits as motivation for employee performance is seen to have certain drawbacks which can undermine the purpose for its uses in organization. The fact is that monetary rewards yield temporary compliance and fails to act as a permanent or long-term motivational tool. Monetary rewards are the main source of employee motivation however, there are contradictory views as to the effectiveness of monetary rewards on employee in the long run. Researches point out that employees in general and more experienced employees specifically are motivated through nonfinancial rewards like work life balance, personnel appreciation, challenging tasks, special projects and so on (Jeffords et al., 1997; Hytter, 2007; Zahra, et al. 2013). Hence, organizations are promised in developing innovative compensation packages that not only includes financial benefits but also non-financial benefits to attract and retain employees for long period (Gibson \& Tesone, 2001; Muralidharan \& Sundararaman, 2011; Zingheim \& Schuster, 2007; Milkovich \& Newman, 2008, Chen \& Hsieh, 2006; Armstrong \& Murlis, 2004). $\mathrm{T}$ conclude, rewards flop to beat into individual employee initiatives, individual desired or their free will and in most cases, assume that without them, the individual cannot be instinctively motivated to perform in their workstation. Therefore, with such experience, managers end up emphasizing the extrinsic rewards (money) to the detriment of the intrinsic ones which will enhance the overall organisational performance.

\section{Conclusion and Recommendation}

As we move into next decade, the objective of setting up and managing performance systems in organizations is to improve employee performance and to drive growth and profitability. Unfortunately, many performance 
management systems are rarely effective. Part of the reason for this inefficacy is that, most companies get the goal setting process wrong. Organizations across all business sectors have continued to move away from traditional annual appraisals, striving for a simpler, more effective performance management system that is ongoing throughout the year. To stay ahead and to cope up with the intense competition among business organizations, the authors intended to provide few suggestions on the basis of this research.

Firstly, for keeping employees performance fit and best it is necessary to detect and adrees the mental health issues as earliest is a key to success. Organisation advancing from the competitors always think forward and they are up to the fact that mental health issues play a serious role in terms of performance and productivitythe issues of wellbeing and employee performance go hand in hand.

Secondly, the number of feedback isn't a fact that will dramatically change the workforce and productivity of employees, but to achieve genuine performance gains, organizations frequent feedback needs to accompany by regular coaching conversations. Coaching conversations and continuous learning have been driving power for Microsoft CEO Satya Nadella, which has heavily pushed Microsoft with resounding success.

Thirdly, according to (Deloitte's, 2018) Global Human Capital Trends report which focuses on the need for organisation to be more employee friendly and be social enterprises, rather than simply business enterprises. Performance management will become meaningful and human by embedding a culture of regular, authentic performance conversations between employees and managers.

Fourthly, according to Gallup, the biggest factor in terms of employee engagement is an employee's manager. With this in mind, performance management and performance management technology will need to focus more on supporting and empowering people managers to be more effective and enabling employees to bring their best selves to work.

Fifthly, according to the Deloitte Global Human Capital Trends report generated in 2018, it shows $84 \%$ of leaders surveyed said people analytics was one of the most important factors because as companies can collect more and better data on turnover, team interaction, wellbeing, and employee feedback. Regardless of how well-meaning a company's performance intentions, analytics can show what a company's results really are. This can be a very useful mirror, particularly when companies want to tackle issues like diversity and pay equity.

Sixthly, the authors suggest a bold approach to separate performance evaluation from any discussion about employee rewards. The idea of disconnecting formal performance evaluations and reward decisions feels counterintuitive.

Finally, instead of structuring performance discussions around giving feedback, the researchers recommend training everyone - employees, supervisors, managers and executives to instead ask for feedback on a regular basis. Organizations can respond to this matter by providing more employee training and development opportunities, but not the traditional kind. Organizations have to move forward towards micro-learning, which are short, informal, self-directed and mobile-optimized content on single topics. These can be brief videos, webinars, podcasts, or even games that provide learning materials in an easy-to-absorb format.

Funding: self-funded.

Author Contributions: conceptualization, Md Yusuf Hoosein Khan; data curation, Md Zahid Al Mamun; formal analysis, Md Zahid Al Mamun; funding acquisition, Md Zahid Al Mamun, Md Yusuf Hossein Khan; investigation, Md Zahid Al Mamun; methodology, Md Yusuf Hossein Khan; project administration, Md Zahid Al Mamun, Md Yusuf Hossein Khan; resources, Md Zahid Al Mamun, Md Yusuf Hossein Khan; software, Md Zahid Al Mamun; supervision, Md Yusuf Hossein Khan; validation, Md Zahid Al Mamun; visualization, Yusuf Hossein Khan; writing - original draft, Md Zahid Al Mamun; writing - review \& editing, Md Yusuf Hossein Khan.

\section{References}

1. Adkins, Helen (2006). The Laws of Motivation. In Caterer \& Hotelkeeper, 196(4429), 26-33. Available at: http://connection.ebscohost.com/c/articles/21475303/laws-motivation, Accessed on April 20, 2020.

2. Amukwaya, S.I. and Yazdanifard, R. (2014) How a Proper Performance Related Reward System Can Contribute to Work Performance Excellence. Open Journal of Business and Management, 2, 189-194. DOI: 10.4236/ojbm.2014.23023. 
3. Anku-Tsede, O. and Kutin, E. (2013). Total Reward Concept: A Key Motivational Tool for Corporate Ghana. Business and Economic Research, 3(2). Available at: https://doi.org/10.5296/ber.v3i2.4291.

4. Armstrong, M. (2001). A Handbook of Human Resource Management Practice. $8^{\text {th }}$ ed. London: Kogan Page. Available https://www.academia.edu/36159260/Armstrong Handbook of Human Resource Management Practice.

5. Armstrong, M. (2009). Armstrong's Handbook of Human Resource Management (11 ${ }^{\text {th }}$ ed.). London: Kogan Page Ltd. Available at: https://www.scirp.org/(S(lz5mqp453edsnp55rrgjct55))/reference/ReferencesPapers.aspx?ReferenceID= 1624804.

6. ASTD (2004). Alexandria, VA. A "Five Ms" Perspective on Leadership vs. Management. Available at: https://www.td.org/newsletters/atd-links/a-five-ms-perspective-on-leadership-vs-management, Accessed on May 28, 2020.

7. Barth, E., Bratsberg, B., Haegeland, T. and Raaum, O. (2008) Who Pays for Performance? International Journal of Man- power and Management, 29, 8-29. Available at: https://doi.org/10.1108/01437720810861985.

8. Bourne, M., Franco, M. and Wilkes, J. (2003). Corporate performance management. Measuring Business Excellence; p. 15. Available at: https://doi.org/10.1108/13683040310496462.

9. Brewster, C., Sparrow, P. and Vernon, G. (2007), International Human Resource Management, 2nd Ed, Wimbledon, Chartered Institute of Personnel and Development, C.I.P.D. Publishing. Available at: http://www.cipd.co.uk/Bookstor...981599.htm, Accessed on May 08, 2020.

10. Businesshumanizer (2017), Book review: A Theory of Human Motivation, Available at: http://www.humanbusiness.eu/maslows-hierarchy-of-needs/, Accessed on March 29, 2020.

11. Cao, Z., Chen, J., and Song, Y. (2013). Does Total Rewards Reduce the Core Employees' Turnover Intentions? International Journal of Business and Management, 8(20), pp. 62-75. DOI: 10.5539/ijbm.v8n20p62.

12. Chen, H. M., and Hsieh, Y. H. (2006). Key Trends of the Total Reward System in the $21^{\text {st }}$ Century. Compensation and Benefits Review, 38(6), 64-70. Dublin. Available at: https://doi.org/10.1177/0886368706292542.

13. Deloitte Global Human Capital Trends (2018). Deloitte Development LLC. Available at: https://www2.deloitte.com/content/dam/Deloitte/at/Documents/human-capital/at-2018-deloitte-humancapital-trends.pdf, Accessed on March 20, 2020.

14. Durrani, S., \& Singh, P. (2011). Women, Private Practice and Billable Hours' Time for a Total Rewards Strategy? Compensation \& Benefits Review, 43(5), 300-305. Available at: https://doi.org/10.1177/0886368711416434.

15. Gibson, J. W., and Tesone, D. V. (2001). Management Fads: Emergence, Evolution, and Implications for Managers. Academy of Management Executive, 15(4), 122-133. Available at: https://www.jstor.org/stable/4165791, Accessed on April 10, 2020.

16. Glendinning Peter (2002). Performance management: Pariah or Messiah, Public Personnel Management, 31(2), 161-178. Available at: https://doi.org/10.1177/009102600203100203.

17. Gross, R., Elhaynay, A., Friedman, N. and Buetow, S. (2008) Pay for Performance in Islaeli Sick Funds. Journal of Health and Management, 22, 23-35. Available at: https://doi.org/10.1108/14777260810862380.

18. Hamukwaya, S.I., \& Yazdanifard, R. (2014). How a Proper Performance Related Reward System Can Contribute to Work Performance Excellence. Available at: http://dx.doi.org/10.4236/ojbm.2014.23023.

19. Heinen, J. S., and O'Neill, C. (2004). Managing talent to maximise performance. Employment Relations Today, 31(2), 67-82. Available at: https://doi.org/10.1002/ert.20018.

20. Holbeche, L. (2009). Aligning Human Resources and Business Strategy (2 ${ }^{\text {nd }}$ ed.) Oxford: Elsevier. Available at: chromeextension://ohfgljdgelakfkefopgklcohadegdpjf/https://www.lsms.ac/public/uploads/SPSB4qlw3JO38a1 ZaBsEiDcF2RnCt3nkIgqWdgi4eQMabHhEmg15752357880zfdKWiWnsmbKFOmygli5gQ78JgyQy50 grmfGSAQSqB7vrnPJU.pdf.

21. Holland, P., Sheenan, C. and De Cieri, H. (2007). Attracting and Retaining Talent: Exploring Human Resources Development Trends in Australia. Human Resource Development International, 10(3), 247262. Available at: https://doi.org/10.1080/13678860701515158. 
22. Hom, P. W., Roberson, L., and Ellis, A. D. (2008). Challenging Conventional Wisdom about Who Quits: Revelations from Corporate America. Journal of Applied Psychology, 93, 1-34. https://doi.org/10.1037/0021-9010.93.1.1.

23. Hytter, A. (2007). Retention Strategies in France and Sweden. The Irish Journal of Management, 28(1), 59-79. Available at: https://www.questia.com/library/journal/1P3-1429543071/retention-strategies-infrance-and-sweden, Accessed on April 18, 2020.

24. I.D.S. (2007). Performance Management, HR Studies, Income Data Services, London. Available at: https://www.e-reward.co.uk/news/new-ids-study-on-performance-management, Accessed on April 08, 2020.

25. Jeffords, R., Scheidt, M., and Thibadoux, G. M. (1997). Getting the Best from Staff. Journal of Accountancy, 184(3), 101-105. Available at: https://www.journalofaccountancy.com/issues/1997/sep/getting.html, Accessed on April 16, 2020.

26. John Shields (2007). Managing employee performance and reward, Cambridge University Press. Asia Pacific Journal of Human Resources, 46. Available at: https://doi.org/10.1177/10384111080460010903.

27. Khan, M.Y.H. (2018). Strategic Human Resource Practices and its Impact on Performance towards Achieving Organizational Goals. Business Ethics and Leadership, 2(2), 66-73. Available at: 10.21272/bel.2(2).66-73.2018.

28. Kuruvilla, S. and Ranganathan, A. (2010). Globalization and Outsourcing: Confronting New Human Resource Challenges in India's Business Process Outsourcing Industry. Industrial Relations Journal, 41(2), 136-153. DOI: $10.1111 / \mathrm{j} .1468-2338.2009 .00559 . x$.

29. Lussier, R.N. (2009). Management Fundamentals: Concepts, Applications and Skill Development. South Western Cengage Learning, Mason. Available at: https://edge.sagepub.com/lussier8e, Accessed on April 26, 2020.

30. MacMahon, J. (1996). Employee relations in small firms in Ireland: An exploratory study of small manufacturing firms, Employee Relations, 18(5), 66-80. Available at: https://doi.org/10.1108/01425459610129399.

31. Malhotra, N., Budhwar, P., \& Prowse, P. (2007 December). Linking Rewards to Commitment: An Empirical Investigation of four UK call centres. In International Journal of Human Resource Management, pp. 2095-2127. Available at: https://doi.org/10.1080/09585190701695267.

32. McMahon, G. (2009). Successful Performance Management: Effective Strategy, Best Practice And Key Skills, Liffey Press, Dublin. Available at: https://www.amazon.co.uk/Successful-PerformanceManagement-Effective-Strategy/dp/1905785704.

33. Md. Shafiullah, Mirza Mohammad Didarul Alam, Farjana Quader, (2011). Practices of Performance Management System in Bangladesh: An Empirical Study among Three Different Industries. Eastern University Journal, 3(1). Available at: [http://dspace.easternuni.edu.bd:8080/xmlui/handle/123456789/76], Accessed on April May 27, 2020.

34. Medcof, J. W., and Rumpel, S. (2007). High Technology Workers and Total Rewards. Journal of High Technology Management Research, 18, 59-72. Available at: https://doi.org/10.1016/j.hitech.2007.03.004.

35. Milkovich, G. T. and Newman, J. M. (2008). Compensation, $\left(9^{\text {th }}\right.$ ed.). USA: McGraw Hill International Edition. Available at: https://www.worldcat.org/title/compensation/oclc/749120988.

36. Muralidharan, K., and Sundararaman V. (2011). Teachers Performance Pay: Experimental Evidence from India. Journal of Political Economy, 119, 845-863. Available at: https://www.nber.org/papers/w15323, Accessed on May 19, 2020.

37. Pamela, R. (2003). Retention Reflects Leadership Style. Nursing Management, 34(8), 18-19. DOI: 10.1097/00006247-200308000-00008.

38. PSYCH 484 (2016). Work Attitudes and Job Motivation. Available at: https://wikispaces.psu.edu/display/PSYCH484/CASE+STUDY+Fall+2016, Accessed on May 13, 2020.

39. Reiche, S. (2007). The effect of International Staffing Practices on Subsidiary Staff Retention in Multinational Corporations. The International Journal of Human Resource Management, 18(4), 523-536. Available at: https://doi.org/10.1080/09585190601178711.

40. Samuel, M. O., and Chipunza, C. (2009). Employee Retention and Turnover: Using Motivational Variables as a Panacea. African journal of Business Management, 3(8), 410-415. DOI: $\underline{10.5897 / A J B M 09.125 .}$ 
41. Sheridan, J. E. (1992). Organizational Culture and Employee Retention. Academy of Management Journal, 35, 1036-1054. Available at: https://doi.org/10.5465/256539.

42. Sweeney, A. P., and McFarlin, D. (2005). Wage Comparisons with Similar and Dissimilar Others. Journal of Occupation and Organizational Psychology, 78(1), 113-131. Available at: https://doi.org/10.1348/096317904X23808.

43. Thompson, James R (2007). Designing and implementing Performance-Oriented Pay band Systems, IBM Centre for the Business of government. Available at: http://www.businessofgovernment.org/sites/default/files/ThompsonPaybandReport.pdf, Accessed on May 30, 2020.

44. Tsai, K.H., Chou, C. and Chen, M.Y. (2008) Does Matching Pay Policy with Innovation Strategy Really Improve Firm Performance? An Examination of Technology-Based Service Firms. Personnel Review, 37 (3), 300-316. https://doi.org/10.1108/00483480810862288.

45. Tsun, J.C., Shang, P.Y. and I-Jan, Y. (2007). The Effects of Joint Reward System in New Product Development. International Journal of Manpower, 28 (3), 276-297. Available at: https://doi.org/10.1108/01437720710755254.

46. Varma, A., Budwhar, P. and DeNisi, A. (2008). Performance Management Systems: A Global Perspective, Routledge, London and New York. Available at: https://www.routledge.com/PerformanceManagement-Systems-A-Global-Perspective/Varma-Budhwar-DeNisi/p/book/9780415771771, Accessed on May 21, 2020.

47. Zahra, S., Irum, A., Mir, S., and Chisti, A. (2013). Job Satisfaction and Faculty Turnover intentions: A Case of Pakistani Universities. Journal of Business and Management, 9(2), pp. 83-89. Available at: http://sajms.iurc.edu.pk/issues/2012b/Fall2012V6N2P3.pdf, Accessed on May 29, 2020.

48. Zingheim, P. K., and Schuster, J. R. (2008). Developing Total Pay Offers for High Performers. Compensation and Benefits Review, 40, pp. 55-59. Available at: https://www.paypeopleright.com/Developing_Total_Pay_Offers_for_High_Performers.pdf, Accessed on April 20, 2020. 